\title{
Erratum to: Pilot study comparing the leak pressure of the sleeved stomach with and without reinforcement
}

Julio López-Monclova $\cdot$ Eduardo Targarona $\cdot$

Carmen Balague $\cdot$ Ramon Vilallonga $\cdot$

Karime Rodríguez-Gómez • Miguel Baeza-Vitolas

Published online: 8 October 2013

(C) Springer Science+Business Media New York 2013

\section{Erratum to: Surg Endosc}

DOI 10.1007/s00464-013-3123-0

The last names of the second and third authors are misspelled. The correct spelling is Eduardo Targarona and Carmen Balague.

The online version of the original article can be found under doi:10.1007/s00464-013-3123-0.

J. López-Monclova ( $\square)$

Department of Surgery, HGZ 35, Mexican Institute of Social Security, C. Valentín Fuentes 2582, 32600 Juarez, Chihuahua, Mexico

e-mail: juliocesar1701@icloud.com

E. Targarona $\cdot$ C. Balague

Department of Surgery, Hospital de la Santa Creu i Sant Pau, Barcelona, Spain

R. Vilallonga

Department of Surgery, Hospital Vall d'Hebron, Barcelona, Spain

K. Rodríguez-Gómez · M. Baeza-Vitolas

Department of Surgery, HGZ 11, Mexican Institute of Social

Security, Delicias, Chihuahua, Mexico 